\title{
Hybrid Energy System with Optimized Storage for Improvement of Sustainability in a Small Town
}

\author{
Fengchang Jiang ${ }^{1,2} \mathbb{1}$, Haiyan $\mathrm{Xie}^{3, *}$ and Oliver Ellen ${ }^{3}$ \\ 1 Taizhou Polytechnic College, Taizhou 225300, Jiangsu, China; jfc1970@163.com \\ 2 Tongji University Complex Engineering Management Research Institute, Shanghai 200092, China \\ 3 Department of Technology, College of Applied Science and Technology, Illinois State University, Normal, \\ IL 61790-5100, USA; ojellen@ilstu.edu \\ * Correspondence: hxie@ilstu.edu; Tel.: +1-309-438-2611
}

Received: 30 April 2018; Accepted: 13 June 2018; Published: 15 June 2018

\begin{abstract}
With the rise of renewable energy comes significant challenges and benefits. The current studies on the incorporation of renewable-energy policies and energy-storage technologies attempt to address the optimization of hybrid energy systems (HESs). However, there is a gap between the currents needs of HES in small towns for energy independence and the understanding of integrated optimization approaches for employing the technology. The purpose of this research is to determine the technical, systematic and financial requirements needed to allow a city or community to become independent of the utilization of traditional energy and develop a reliable program for a clean and environment-friendly energy supply. This paper presents the sensitivity analysis and Bayesian prediction (SABP) method for the optimized design of a hybrid photo-voltaic wind energy system. This method uses the actual data to analyze and compare the main, optimized and desired scenarios of HES designs. The results show that optimized design can minimize the cost of the energy generated while reliably matching local electricity demand. The SABP system helps to eliminate the dependence on traditional energy resources, reduce transition costs by purchasing electricity, and decrease the financial burden of a small city.
\end{abstract}

Keywords: renewable energy; independent energy resources; solar; wind; energy storage; Bayesian analysis; prediction

\section{Introduction}

Many cities or communities are seeking sustainable access to energy. Some implementations of renewable energy systems utilize omnipresent and environmentally friendly resources [1,2]. Although the energy resources may seem to be promising individually, their stochastic nature hinders their reliability due to other environmental factors or the inability to sustain required amounts by themselves [3]. For example, solar power relies on the duration, intensity, and angle of sunlight. But weather is unpredictable. Therefore, it is common practice to combine two or more renewable energy resources, sometimes with traditional energy resources, into a hybrid energy system (HES). Nevertheless, there are challenges with HES implementation. One major challenge is how to optimize the HES system to allow a city or community to become independent of traditional energy supplies.

\subsection{Research Targets}

The purpose of this research is to determine the technical and systematic requirements to allow a community to utilize more renewable energy. The target is to develop a reliable program for clean and environment-friendly energy supply. This paper aims to review several types of projects developed in different HESs of real implementation and evaluation studies. Based on critical reviews, the paper 
documents the system analyses and decision-making-processes in a city with a population of less than 100,000. The research identifies the determinant factors for the success of implementation, which are community characterization, energy demand, and proposed technical solution. According to "Sustainable Development Goal 7: Ensure access to affordable, reliable, sustainable and modern energy for all" among the Sustainable Development Goals SDG2015-2030 [4], to switch to sustainable energy the world should triple its investment in sustainable energy infrastructure annually until 2030, which requires an increase from approximately $\$ 400$ billion in 2015 to $\$ 1.25$ trillion by 2030 . The goal encourages countries and businesses to accelerate the transition to an affordable, reliable, and sustainable energy system and maintain and protect ecosystems. It suggests businesses pledge to source $100 \%$ of effective electricity requirements from renewable sources [4].

The significance of this work is that the HES design innovatively created an energy utilization program for a small town and optimized its configuration. The analysis results show the system's capability to solve the sustainable-development obstacles faced by small towns and communities. The practical advantages of this designed configuration include strong reliability and substantial reduction of the costs for generating energy. The research can broadly impact multiple administrative and energy supply divisions in the process of sustainable management for renewable energy globally.

\subsection{Literature Review}

Recently, researchers have paid increased attention to alternative and renewable power-generation methods that are effective, such as wind, hydropower, solar, geothermal, and bio energy [5-10]. Renewable energy is often used to displace conventional fuels in four areas: electricity generation, hot water/space heating, transportation, and rural (off-grid) energy services [11,12]. Even though renewable energy sources have multiple benefits for the environment, economy, and health, there is considerable debate criticizing the deployment of renewable technology. The emerging technology includes: (1) enhanced geothermal systems (EGS); (2) cellulosic ethanol; (3) marine energy (or ocean energy); (4) wind power; and (5) solar energy. The EGSs are independent of natural convective hydrothermal resources and obtain geothermal energy in dry and non-porous rock [13]. These geothermal reservoirs have limited availabilities in only certain areas, which usually are adjacent to tectonic zones with active or semi-active volcanos. The EGS overcomes the restriction and has potential for wide implementation [14]. EGS technology is able to produce power continuously and is feasible for most areas in the world. However, the technology depends on the economic limits of drill depth $[13,14]$. Cellulosic ethanol technology processes biomass, which is turned into ethanol in refineries. Its commercialization process relies on enzymes and might offer opportunities for farmers and biotechnology firms [9,15]. Ocean waves, tides, salinity, and the difference in ocean temperature can create marine energy satisfying a substantial amount of needs around the world [16]. Marine energy conversion (MEC) technology is at a blossoming stage of development [17]. Derived by wind turbines, wind energy is one of the fastest-growing energy sources and offers many advantages, including effective cost, job creation, industrial growth, increased viability, clean fuel resources, a domestic source of energy, sustainable systems, and easy installation for rural areas [18]. The organization of wind turbines focuses on prearranged operations and maintenance strategies to ensure safety, profitability and cost-effectiveness [2]. To avoid price volatility and reduce the difference between supply and demand, the day-ahead energy market allows market participants to commit towards buying or selling wholesale electricity one day before the operation, which is an important step toward the financial stability of wind power production $[19,20]$. Researchers noticed that the fickle nature of forecast errors frequently compromised a wind farm operator from holding a well-founded production commitment $[20,21]$. The development of solar energy technologies displays diversity [22]. The electricity generation of concentrated photovoltaic (CPV) systems converts a temperature difference between dissimilar materials into an electric current using thermoelectric (or thermo-voltaic) devices [23]. After the establishment of the first commercial CPV plant in the 1980s, the number of grid-connected CPV systems has grown to the millions [24-26]. The capacity 
of utility-scale solar power stations can reach the level of hundreds of megawatts, which contributes to the decrease of the cost of solar electricity [26-29]. Solar thermal technologies have the benefits of low-carbon emissions and inexpensive operation costs $[25,26]$. Other solar technologies include floating solar arrays and assisted heat pumps, artificial photosynthesis, solar updraft towers, space-based solar power, etc. [30-32]

HES design needs to consider multiple factors. For example, in a technical and economic analysis of a HES with coal, wind, and nuclear energy, the system engages a co-electrolysis unit using $\mathrm{CO}_{2}$ as a feedstock for the production of synthetic gas and subsequent fuels and chemicals [33]. The operational units of this HES are the coal/biomass-fed pressurized circulating fluidized bed (PCFB), Benfield process unit, Westinghouse small modular reactor (SMR), high-temperature steam electrolysis (HTSE) unit, etc. The total process hybridization starts after each operational unit is individually completed and converged to achieve different simulation options and overall simplicity. The process of this coal-wind-nuclear HES consists of the following steps: (1) feed coal and air into the PCFB combustor to produce electricity and an effluent stream; (2) send the stream into the Benfield air scrubber to generate a pure $\mathrm{CO}_{2}$ stream; (3) modify the temperature and pressure of the $\mathrm{CO} 2$ stream to prepare it for the HTSE unit; (4) recycle the produced oxygen back for air enrichment into the PCFB combustor. Then, the rest of the product synthesis gas is ready for other forms of utilization. The results reflect the hybridization of the enriched air stream, with increased robustness in terms of efficiency and accuracy. This system produces multiple products from a HES. However, the research analysis of Buchheit et al. [33] does not include data or discussion to explain how sound is the economic performance of this system. Meanwhile, Yousefi and Ghodusinejad discussed a technical feasibility study of a HES (renewable and non-renewable resources and energy storage system) for a Disaster Management Basement located in Tehran, Iran [34]. The simulation of the research was concentrated on potential power blackouts caused by disasters. Due to the unforeseeable occurrences of disasters, the research simulation of the system only lasted for a year. They also used a sensitivity analysis to calculate system reliability. They found that with diesel prices up to $0.5-0.6 \$ / \mathrm{L}$, the only optimal power system was a diesel generator. If the diesel price was more expensive, wind and solar power sources should be added. The limitations of the paper include the fact that it is only for an exclusively small-sized building and only the diesel price is considered.

Some renewable-energy programs in small towns, cities and municipalities attempt to address the optimization of HES [35,36]. However, there is a gap between the current needs of HES in small towns for energy independence and the understanding of integrated optimization approaches for HES uses [36-38]. In this feasibility study on a Canada resort, the owners wanted to decide if renewable energy resources were the best option [38]. The study analyzed the costs of varied renewable-energy resources that could be used. Using HOMER Pro ${ }^{\circledR}$ software [39] to evaluate the benefits of each potential system, the study concluded that the best system to implement for the resort was a grid-connected system without renewable-energy resources. This was because the initial costs of the system would never be paid back if using only renewable energy.

\subsection{Intellectual Contribution}

This paper presents a sensitivity analysis and Bayesian prediction (SABP) method for an optimized design of the hybrid photovoltaic-wind energy system. The novelty of this paper lies in exploring the feasibility study of renewable energy by using SABP method to analyze both calculated and real-world data, from which a practical conclusion is drawn. The main objectives are to determine the reliability and predictive capability of survey results and develop a strategy for formulating and selecting optimally preferred HES configuration. The SABP can be used for estimating costs and risks associated with system selection. The method can help in risk-based decision-making where cost-risk trade-off analysis can be brought about efficiently and effectively for policy and regulatory purposes $[40,41]$. An expert opinion is predictive if based on the results along, there is a reasonable degree of confidence on the feasibility of the tested HES system. The expert opinion is $\mathrm{p} \%$ predictive if there is a $\mathrm{p} \%$ 
chance that each prediction given by the test is correct. Appendix A has the details of the equation definitions for the ability of the expert surveys to predict feasibility, which can be characterized by analyzing the test results as to sensitivity, specificity, and accuracy. The expert surveys are able to provide data to characterize the HESs and predict their feasibilities. Equations in Appendix A define and analyze the feasibility of the test results [40]. This paper innovatively implemented the Bayes formula, the sensitivity and specificity of a test, and the probability to justify if a tested HES is feasible. By contrast with the study of Buchheit et al. [33], this paper discusses in detail how economic conditions and considerations affected the HES selection. This method uses the actual hourly data of wind speeds, solar radiation, temperature, and electricity demand in a town in Illinois, U.S. The SABP method varies from the simulation and sensitivity analysis suggested by Yousefi and Ghodusinejad [34]. The SABP method is able to perform multi-objective analysis for medium to large scales of implementation, whereas the latter only worked on one small building. The SABP method is able to obtain the minimum cost of the energy generated while reliably matching local electricity demand. The tests of the method consider a real case study with actual situations. To estimate how substantial the cost saving is compared to the actual situation costs, this research calculates electricity demand from the utility grid using the market prices of electricity. The results show that the selected HES configuration is an optimized solution for the target location. The results also indicate that the proposed method is effective at responding to the expected changes in the system parameters and variables while providing a reliable sizing solution. The SABP method is appropriate for assessing the effectiveness of a HES arrangement.

\section{Materials and Methods}

\subsection{Method Design}

To predict the feasibilities (FE for feasible and NF for not feasible) of potential HES designs, this research develops the SABP method for a specific situation. Consider a series of tests $A_{1}, A_{2}, \ldots, A_{n}$ whose sensitivities $\alpha_{1}^{+}, \alpha_{2}^{+}, \ldots, \alpha_{n}^{+}$and specificities $\alpha_{1}^{-}, \alpha_{2}^{-}, \ldots, \alpha_{n}^{-}$are known. For HES configuration, the series of tests will help to identify an optimized solution [35]. Using $\theta_{i}^{+}=\operatorname{Pr}\left(F E \mid A_{1}, A_{2}, \ldots, A_{i}\right)$ and $\theta_{i-1}^{-}=\operatorname{Pr}(N F)$ when $A_{i}$ shows a positive result, Equations (1)-(8) define the SABP method. Equation (8) has the condition when $A_{i}$ shows a negative result.

$$
\begin{aligned}
& \theta_{1}^{+\mid+}=\operatorname{Pr}\left(F E \mid A_{1}=+\right)=\frac{\operatorname{Pr}(F E) \operatorname{Pr}\left(A_{1}=+\mid F E\right)}{\operatorname{Pr}(F E) \operatorname{PrPr}\left(A_{1=}=\mid F E\right)+\operatorname{Pr}(N F) \operatorname{Pr}\left(A_{i=}+\mid N F\right)}=\frac{\theta_{0}^{+} a_{1}^{+}}{\theta_{0}^{+} a_{1}^{+}+\left(1-\theta_{0}^{+}\right)\left(1-a_{1}^{-}\right)}=\frac{\theta_{0}^{+} a_{1}^{+}}{\left(1-a_{1}^{-}\right)+\left(a_{1}^{+}+a_{1}^{-}-1\right) \theta_{0}^{+}} \\
& \theta_{1}^{+\mid-}=\operatorname{Pr}\left(F E \mid A_{1}=-\right)=\frac{\operatorname{Pr}(F E) \operatorname{Pr}(-\mid F E)}{\operatorname{Pr}(F E) \operatorname{PrPr}\left(A_{1=}=-\mid F E\right)+\operatorname{Pr}(N F) \operatorname{Pr}\left(A_{i=-} \mid N F\right)}=\frac{\theta_{0}^{+}\left(1-a_{1}^{+}\right)}{\theta_{0}^{+}\left(1-a_{1}^{+}\right)+\left(1-\theta_{0}^{+}\right) a_{1}^{-}}=\frac{\theta_{0}^{+}\left(1-a_{1}^{+}\right)}{\left(a_{1}^{-}\right)-\left(a_{1}^{+}+a_{1}^{-}-1\right) \theta_{0}^{+}}
\end{aligned}
$$

Repeat the application of Bayes' theorem, which yields a general recursive formula for predictability.

$$
\theta_{i}^{+\mid+}=\frac{\theta_{i-1}^{+} a_{i}^{+}}{\left(1-a_{i}^{-}\right)+\left(a_{i}^{+}+a_{i}^{-}-1\right) \theta_{i-1}^{+}}
$$

If $A_{i}$ shows a positive result, $i=1,2, \ldots, n$,

$$
\theta_{i}^{+\mid-}=\frac{\theta_{i-1}^{+}\left(1-a_{i}^{+}\right)}{\left(a_{i}^{-}\right)-\left(a_{i}^{+}+a_{i}^{-}-1\right) \theta_{i-1}^{+}} .
$$

If $A_{i}$ shows a negative result, $i=1,2, \ldots, n$,

$$
\theta_{i}^{+}= \begin{cases}\theta_{i}^{+\mid+} & \text {if } A_{i}=+, i=1,2, \ldots, n \\ \theta_{i}^{+\mid-} & \text {if } A_{i}=-, i=1,2, \ldots, n\end{cases}
$$


If $A_{i}$ shows a positive result at the $i$ th stage, $i=1,2, \ldots, n$,

$$
\begin{gathered}
\theta_{i}^{-\mid+}=\operatorname{Pr}\left(N F \mid A_{i}=+\right)=\frac{\operatorname{Pr}(N F) \operatorname{Pr}\left(A_{i}=+\mid N F\right)}{\operatorname{Pr}(N F) \operatorname{Pr}\left(A_{i}=+\mid N F\right)+(1-\operatorname{Pr}(N F)) \operatorname{Pr}\left(A_{i=}+\mid F E\right)} \\
\theta_{i}^{-\mid+}=\frac{\theta_{i-1}^{-}\left(1-a_{i}^{-}\right)}{\left(a_{i}^{+}\right)-\left(a_{i}^{+}+a_{i}^{-}-1\right) \theta_{i-1}^{-}}, \\
\theta_{i}^{-\mid-}=\operatorname{Pr}\left(N F \mid A_{i}=-\right)=\frac{\operatorname{Pr}(N F) \operatorname{Pr}\left(A_{i}=-\mid N F\right)}{\operatorname{Pr}(N F) \operatorname{Pr}\left(A_{i}=-\mid N F\right)+(1-\operatorname{Pr}(N F)) \operatorname{Pr}\left(A_{i}=-\mid F E\right)}= \\
\frac{\theta_{i-1}^{-} a_{i}^{-}}{\theta_{i-1}^{-} a_{i}^{-}+\left(1-\theta_{i-1}^{-}\right)\left(1-a_{i}^{+}\right)}=\frac{\theta_{i-1}^{-} a_{i}^{-}}{\left(1-a_{i}^{+}\right)+\left(a_{i}^{+}+a_{i}^{-}-1\right) \theta_{i-1}^{-}},
\end{gathered}
$$

Before the research was conducted, the authors interviewed subject matter experts (SMEs) for the study. Using the results of a literature review and empirical studies of real-world cases, as well as the input of two external advisers on the project, the authors designed the survey questions [42-44]. The authors participated the creation of the survey questions and sent the email and mail surveys out to the participants. The survey was anonymous. Then, the data was calculated in a multistep process of the SABP system.

\subsection{Materials}

\subsubsection{Participants and Context}

The study took place within the U.S. Since the survey was delivered in email, mail and phone call formats, the participants completed the study in whichever environments they preferred. The study incorporated two different research designs, which were exploratory and descriptive. The exploratory design was chosen because of the study explores new ways of evaluating and analyzing multiple HES configurations. In addition, the descriptive design is because the study describes characteristics of the optimized HES.

\subsubsection{Software}

Hybrid Optimization Model for Multiple Energy Resources (HOMER) software not only evaluates the costs and benefits of particular solar systems but also runs analytics that determine if utility grade systems are feasible in certain locations [39]. For the selected city in this study, to overcome its resource challenges using an optimization tool such as HOMER Pro ${ }^{\circledR}$ allows the SABP system to evaluate the most economic and technologically feasible option for the city to incorporate in the future. The SABP system uses HOMER Pro ${ }^{\circledR}$ micro grid software which is the global standard for optimizing micro grid design in all sectors, from village power and island utilities to grid-connected campuses and military bases [39]. Originally, HOMER was developed at the National Renewable Energy Laboratory, and enhanced and distributed by HOMER Energy.

\subsubsection{Site Survey}

The authors interviewed the city's Director of Electrical Operations for data acquisition and the electricity utility portfolio. As a result, Table 1 shows the power content mix of the city and its current means of electricity production, which include: two wind turbines (1.5 MW Vensys model 77) [45], 1.2 MW solar array, eight diesel generators (with 10\% extra capacity at any given point in time in case of grid failures), and 3.69 MW operation ownership of the Louisa Coal plant in Muscatine, IA [46]. The city currently owns $0.5 \%$ of the plant's ownership, whose nameplate capacity is 738 MW [47]. Hence, $0.5 \% \times 738 \mathrm{MW}=3.69 \mathrm{MW}$ is the ownership for the city. The city obtains its remaining power requirement from the electrical grid operated by the Midcontinent Independent System Operator Inc. (MISO). For the electricity that the city cannot produce on site, they purchase from the MISO on the day-ahead market [48]. The day-ahead market is the main arena for trading power where sellers 
and buyers make contracts for the delivery of power the following day. The SABP system uses wind and solar resource data imported from the HOMER Pro ${ }^{\circledR}$ software database. It acquires emission data in the same manner. The system calculates and compares the current and optimized potential contents to propose renewable hybrid systems. The simulation program and the developed data sets provide the following information to decision makers: electricity generation, financial parameters, and environmental impacts.

Table 1. Power content of selected city.

\begin{tabular}{ccc}
\hline Item & Power Content Mix for the Selected City & Power Content Mix from HOMER \\
\hline Source & City's Power Content [49] & Software Simulation \\
1 & $64 \%$ Electricity Purchase. Power MW & $65.86 \%$ Electricity Purchase. Power MW \\
2 & $23 \%$ Louisa Generation (Coal) & $23.36 \%$ Louisa Generation (Coal) \\
3 & $1 \%$ Plant Generation & $0 \%$ Plant Generation \\
4 & $10 \%$ Wind Turbine Generation & $8.2 \%$ Wind Turbine Generation \\
5 & $2 \%$ Solar Generation & $2.57 \%$ Solar generation \\
\hline
\end{tabular}

\section{Results}

\subsection{Energy Sources and Systems}

\subsubsection{Wind}

Currently, the city uses 65,000 to $68,000 \mathrm{MW}$ on an annual basis. Since the city already made the capital investment for the wind turbines, which are functional, this study makes the capital cost equal to zero with a replacement cost equal to $\$ 750,000$. The replacement cost is lower than the actual investment made on the turbines $(\$ 1,700,000)$ due to the fact that it is possible to salvage the existing transmission lines and used parts. The HOMER Pro ${ }^{\circledR}$ model assumes the life expectancy of the turbines to be 30 years. It has been roughly 8 years since the installation of the turbines. Hence their lifetime in the simulation model is 22 years. The operating and maintenance (O\&M) costs are equal to $\$ 30,000$ annually per turbine based on recommendations from the Director of Electrical Operations of the city and the current O\&M costs. The chosen hub height for the wind turbines is $80 \mathrm{~m}$ based on the wind data extrapolated for that region from the software database. The actual height of the Vensys wind turbine model 77 can be $62.5 \mathrm{~m}, 85 \mathrm{~m}$ or $100 \mathrm{~m}$ [45]. This height selection assumes a mean value of the 3 models. Figure 1 shows the power curve representing a generic $1.5 \mathrm{MW}$ turbine. The city has relatively low turbine losses $(>1 \%)$. Therefore, this research excludes turbine losses in the simulation model. The simulation of SABP system excludes maintenance because there has been relatively low maintenance over the past 8 years from the start of operation.

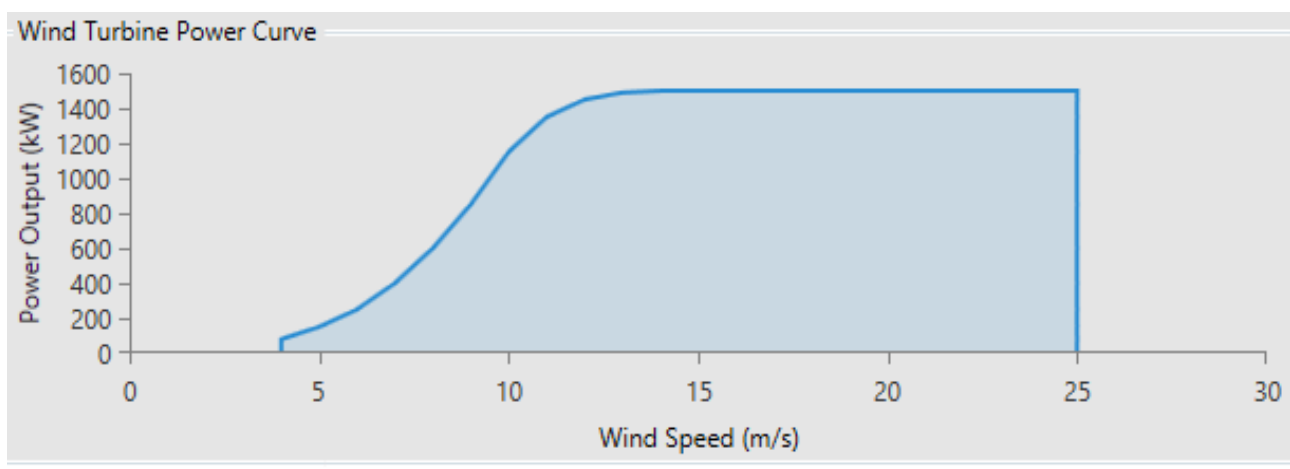

Figure 1. Power curve for generic 1.5 MW wind turbine. 


\subsubsection{Solar}

In 2015, the city installed a solar system with 1.232 MW DC power. The system uses a Universal Solar (WXS290P-US) module of $290 \mathrm{~W}$ each. The system includes 4248 Modules at a fixed tilt angle of $30^{\circ}$. The solar system layout has 18 modules in each string and 6 strings per inverter (with 108 modules per inverter). The inverter is a SMA TRIPOWER 20,000 TL \& 24,000 TL. The city uses the solar system with a quantity of four $20 \mathrm{~kW}$ or 20,000 TL and thirty-six $24 \mathrm{~kW}$ or 24,000 TL.

To model this solar system, the SABP system uses the following data inputs. The panel is a generic flat plate panel rated at a capacity of $1200 \mathrm{~kW}$. The capital costs are zero because the city has already purchased the array. The replacement cost is $\$ 1000$ per $\mathrm{kW}$ because transmission, racks, and mounts for the system could be reused in the future. The calculation of the O\&M costs uses the information obtained through interviews. The O\&M costs per year per $\mathrm{kW}$ are $\$ 5.00$. The average lifetime is 25 years for the whole system. The lifetime expectancy of the system is 23 years because the solar system was installed roughly 2 years ago. The SABP system uses the defaults of the de-rating factor from HOMER Pro ${ }^{\circledR}$ database, which is at $80 \%$ and relatively conservative. There is no tracker for the maximum power point due to the unknown certainty of the information given. The simulation result of the ground reflectance is $20 \%$. The optimization tool does not need to track information of the solar system because the panels are fixed mounted.

\subsubsection{Generators and Grids}

There are eight diesel engines with a total horsepower of 41,615 in the generating plant of the city [49]. The city rarely has to run the generators and obtains less than $1 \%$ of the energy needs from the plant. Hence, this SABP system excludes them in order to simplify the results. The city is unable to generate all of its electricity on site from its renewables, diesel generators and coal plant. The city acquires the remaining electricity from the day-ahead market. It uses locational and marginal pricing hourly to figure out how much the electricity will cost. Using the information acquired from the MISO database $[50,51]$, this SABP system calculates a simple average rate of the electricity price, which is $\$ 0.075$ per $\mathrm{kWh}$. The city is able to sell-back power when its demand is less than consumption, which is usually at night. However, this sellback does not happen very often. To model the city grid, the SABP system uses a simple price rate structure. The grid power price is $\$ 0.075 / \mathrm{kWh}$ based on an average of $\$ 25 \mathrm{LMP}=\$ 0.025 \mathrm{KW}$, with the grid sellback price of $\$ 0$. The transmission costs account for $70 \%$ of the total electricity cost. For the carbon emissions associated with the grid, the SABP system uses the HOMER Pro ${ }^{\circledR}$ defaults, which are $632 \mathrm{~g} / \mathrm{kWh}$ carbon dioxide, $0 \mathrm{~g} / \mathrm{kWh}$ carbon monoxide, $0 \mathrm{~g} / \mathrm{kWh}$ unburned hydrocarbons, $0 \mathrm{~g} / \mathrm{kWh}$ particulate matter, $2.74 \mathrm{~g} / \mathrm{kWh}$ sulfur dioxide, and $1.34 \mathrm{~g} / \mathrm{kW}$ nitrogen oxides.

\subsubsection{Coal}

The coal plant is not always running at full capacity. To include this situation into the simulation, it is necessary to create a fuel source within the system for this coal energy. The coal has $15 \mathrm{MJ} / \mathrm{kg}$ heating value, $1450.00 \mathrm{~kg} / \mathrm{m}^{3}$ density, $65 \%$ carbon content, and $0.4 \%$ sulfur content [28]. The density is in the middle range and the sulfur content is in the upper range of lignite because the Louisa Coal plant is the 71st most polluting coal plant in the U.S. [52] The generator model for the coal energy uses a generic generator with $1800 \mathrm{~kW}$ capacity. This generator model chooses a capacity factor of $49 \%$ to get the value of $1800 \mathrm{~kW}(49 \% \times 3.69 \mathrm{MW}=1.8 \mathrm{MW})$ [53]. This is the average output for the coal plant throughout the entire year. The modeled fuel curve uses a consumption of $816 \mathrm{~kg} / \mathrm{h}[53,54]$.

The SABP system takes the capital and replacement costs of the coal plant into consideration. The costs equal zero because after the lifetime of this coal plant, the city will not purchase another coal plant. The O\&M costs of coal energy is $\$ 0.03 / \mathrm{h}$. The average price for lignite coal is $\$ 22.36$ per short ton of coal [53,54], which means that it costs about half a cent per $\mathrm{kg}$ of coal. The assumed cost of transmission is about 4.5 cents per $\mathrm{kg}$. The price of coal is $\$ 0.05 / \mathrm{kg}$. The emission data per $\mathrm{kg}$ of fuel 
are as follows: $16.34 \mathrm{~g}$ carbon monoxide, $0.72 \mathrm{~g}$ unburned hydrocarbons, $0.098 \mathrm{~g}$ particulate matter, $2.2 \mathrm{~g}$ sulfur content converted to PM, and $15.359 \mathrm{~g}$ nitrogen oxides.

\subsubsection{Load}

Figure 2 uses the city's previous electricity demand (refer to Table 1) and information on its infrastructure. The figure shows the daily profile, seasonal profile and yearly profile of the city.

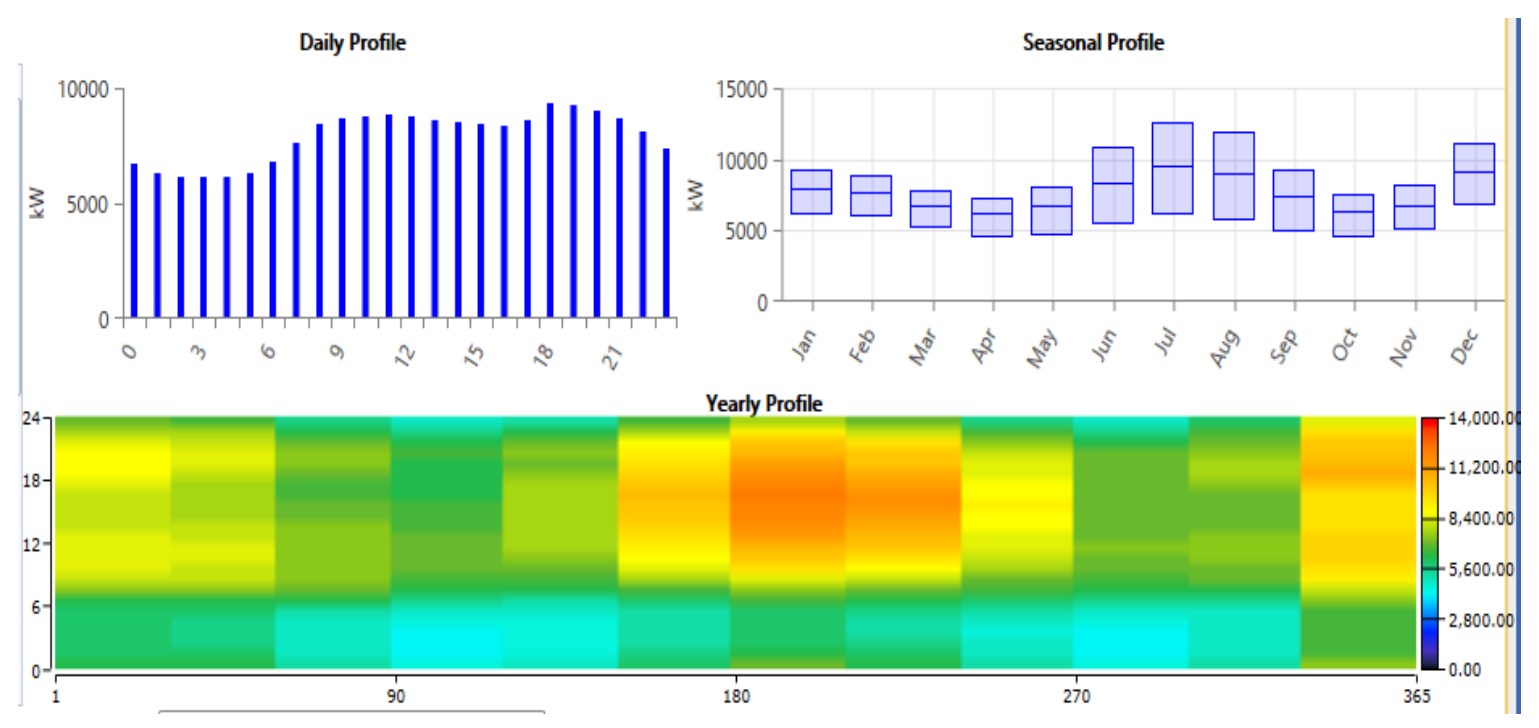

Figure 2. Daily, seasonal, yearly load profiles.

\subsubsection{Solar and Wind Resource Data}

The solar data used in the research comes from the National Renewable Energy Lab Database [55] and National Solar Radiation Data Base [56] for the city according to its latitude and longitude. The scaled annual average of solar rational is $4.28\left(\mathrm{kWh} / \mathrm{m}^{2} /\right.$ day). The wind data comes from the National Aeronautics and Space Administration (NASA) Surface Meteorology and Solar Energy Database [57] collected at $50 \mathrm{~m}$ above the surface of the Earth. Using a wind-speed profile with a logarithmic curve allows this data to scale and compensate for the $80 \mathrm{~m}$ hub height. Other inputs include: $15 \mathrm{mph}$ peak wind speed, 0.85 autocorrelation factor, 0.25 diurnal pattern strength, and $5.5 \mathrm{~m} / \mathrm{s}$ average annual wind speed.

\subsection{Affordability}

The design of the SABP system needs to be affordable to the users. After studying the current economic situation of the city, the system design uses the following data: a $6 \%$ nominal discount rate, $2 \%$ expected inflation rate, and 25-year lifetime. As a disclaimer, no grants or government assistance will be used when calculating the results for this project.

The following information is the input to the SABP system as the current data. Since the city should have electricity at all times, the annual capacity shortage is $0 \%$. For the operating reserve (percentage of renewable output), the load percentages are between $10 \%$ and $0 \%$ in the annual peak load. The solar power output and the wind power output are both $10 \%$. In addition, there are converters already in the current system, the replacement costs of which are $\$ 300.00 / \mathrm{kW}$ based on an expected lifetime of 15 years. The efficiency of the inverter is $95 \%$. The data helps to estimate the amount of renewable energy coming from the system. 


\section{Discussions}

Compared to the designs of HESs or hybrid renewable energy systems (HRES) in [37,38,58], this city has a complex network of electricity facilities, distribution grids, and generation systems. The analysis of the SABP system uses the current industry averages and knowledge of credible energy experts [59]. The industry data and expert knowledge are crucial to make the calculated results accurate and reasonable. The comprehensive design has the following advantages: (1) it is independent of geographical restrictions of natural hydrothermal and marine energy resources $[13,14,16,17]$; (2) it is flexible in energy uses including wind, solar and traditional resources [2,18,22]; and (3) it uses practical and generalizable assumptions for engineers and policy-makers.

For the optimal solar photovoltaic (PV) array, the capital costs are $\$ 1,923,000$ (\$1.93 per watt) and O\&M costs are for $\$ 5.00 \mathrm{KW} /$ year [60]. For the optimized wind turbines the assumptions are as follows: $\$ 1,700,000$ capital costs per turbine, and $\$ 30,000$ in O\&M per wind turbine with a 30-year lifetime. The SABP system simulates the optimized wind turbines with the imported wind data provided by HOMER Pro ${ }^{\circledR}$ for the years 1995-2003 at $50 \mathrm{~m}$ hub height. The system extrapo lates the hub height to $80 \mathrm{~m}$ to improve the accuracy of the wind data. Lastly, the optimized battery storage system assumes capital costs of $\$ 350$ per $\mathrm{kWh}$ for lithium-ion batteries and O\&M costs of $\$ 10$ per $\mathrm{kWh}$ per year with an estimated system lifetime of 8 to 10 years.

\subsection{Main Scenario}

The city wanted to be totally independent from the MISO market when starting this research study to follow the examples of numerous other cities [61]. However, after the SABP system ran the optimization process, it proved that this goal would be unattainable with the current market prices and technology. The total upfront cost of the system would be more than $\$ 184$ million dollars, for which the system was unable to find a payback period within the 25 years of lifetime. In the main scenario, the city would obtain around $20 \%$ of the energy production from solar, $77 \%$ from wind, and the rest from the coal plant. Figure 3 shows the monthly average electrical production graph, with OPV = optimized photovoltaic, O1.5 = optimized 1.5 MW wind turbine, EPV = existing photovoltaic, E1.5 = existing 1.5 MW wind turbine. The city would need 173,667 kWh of Li-ion batteries to supply power, because there is a very high peak demand in the summer months. Figure 4 shows that the state of charge for the batteries is always at $100 \%$. The cost of the batteries would be $\$ 60.7$ million dollars based on the estimates from Tesla's most recent kWh price [62].

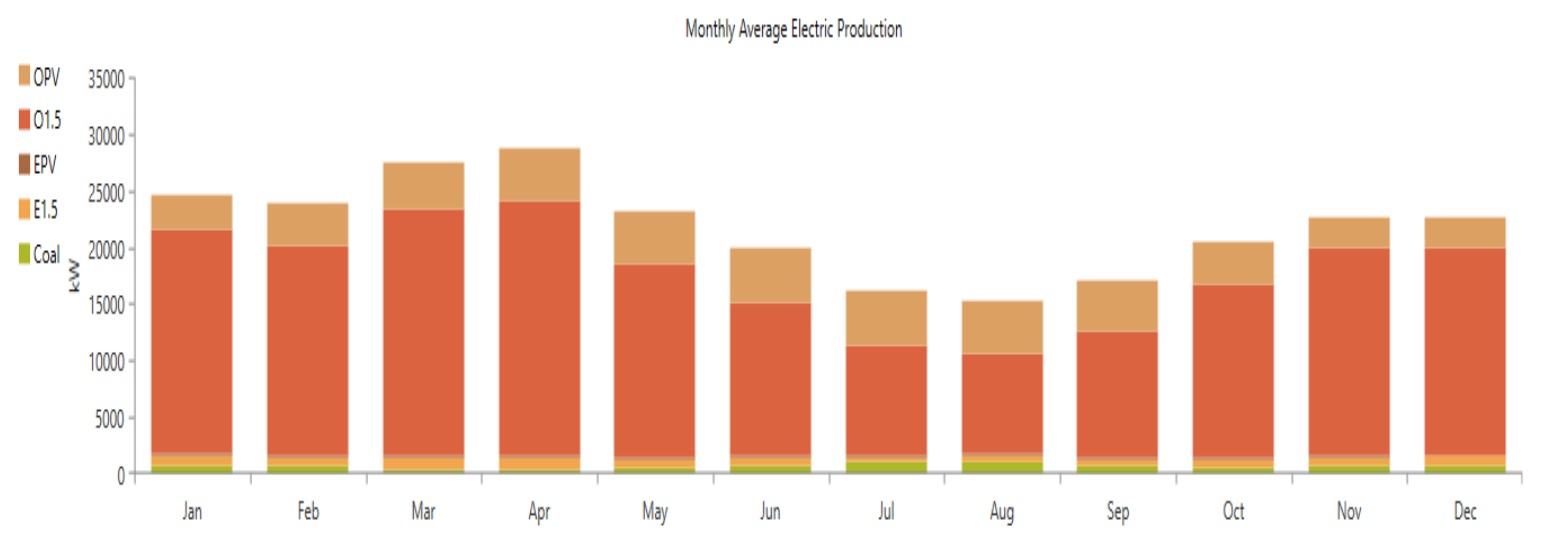

Figure 3. Monthly Average Electric Production of Main Scenario. 


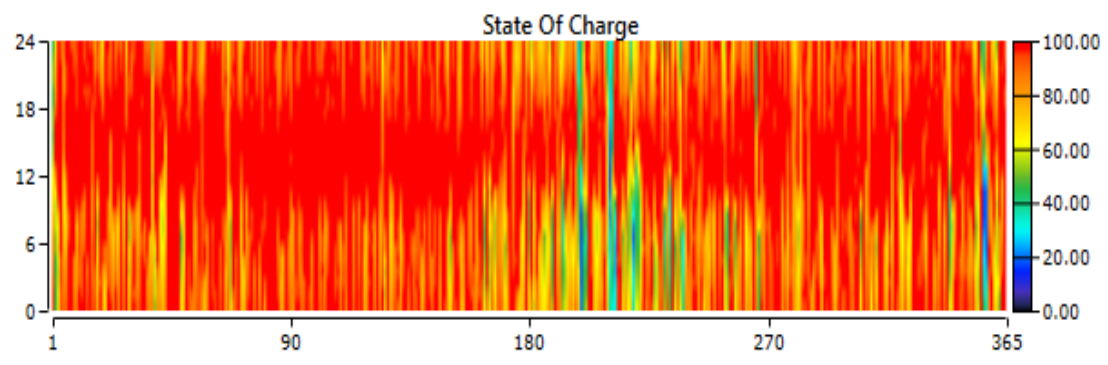

Figure 4. State of charge for batteries.

For the optimized solar energy design, the SABP system would use the 1.2 MW capacity that already exists and add 24.417 MW of additional solar energy. The solar panels would operate 4359 megawatt hours of solar energy per year. The leveled cost of energy for the new panels would be 0.0878 ( $\$ / \mathrm{kWh}$ ). Figure 5 shows the PV power output for the newly optimized solar PV. The upfront financial cost to add $24.417 \mathrm{MW}$ of solar would be $\$ 46.9$ million dollars.

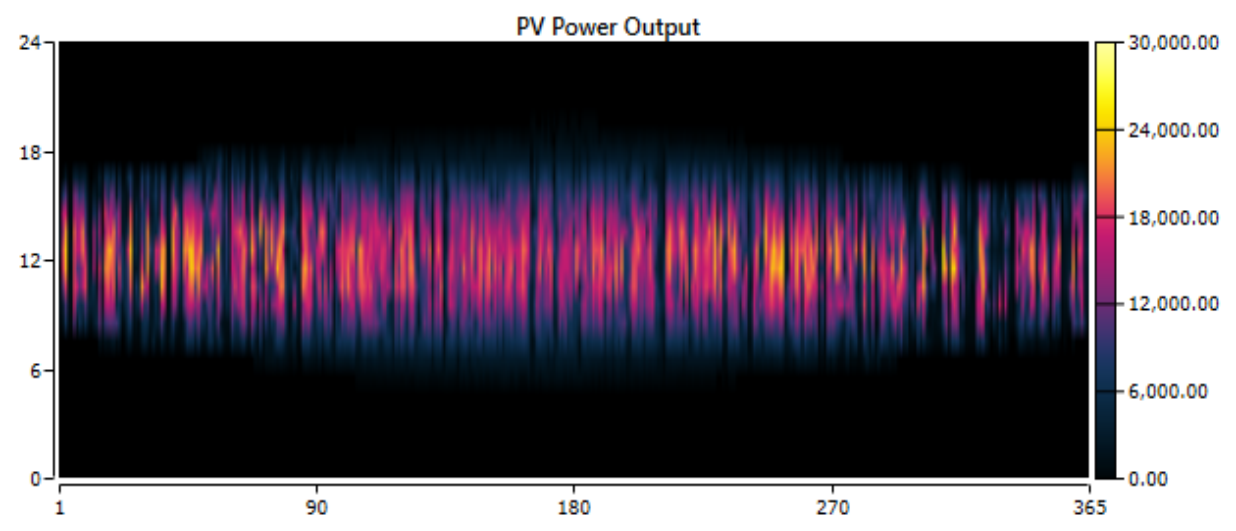

Figure 5. Optimized PV Power Output.

For the optimized wind, the city would utilize the existing two $1.5 \mathrm{MW}$ wind turbines that are on site and add 45 more 1.5 MW wind turbines. This would give a total of $70.5 \mathrm{MW}$ of installed wind capacity. The wind turbines would be operating 6061 h/year. Figure 6 shows the optimized, wind-turbine power output. The leveled cost of adding the new wind turbines would be $\$ 0.04289 / \mathrm{kWh}$. The total financial cost of adding 45 more $1.5 \mathrm{MW}$ wind turbines would be $\$ 76.5$ million. The other costs of the project would include the system converter, replacement costs, O\&M, and fuel costs for the coal power plant.

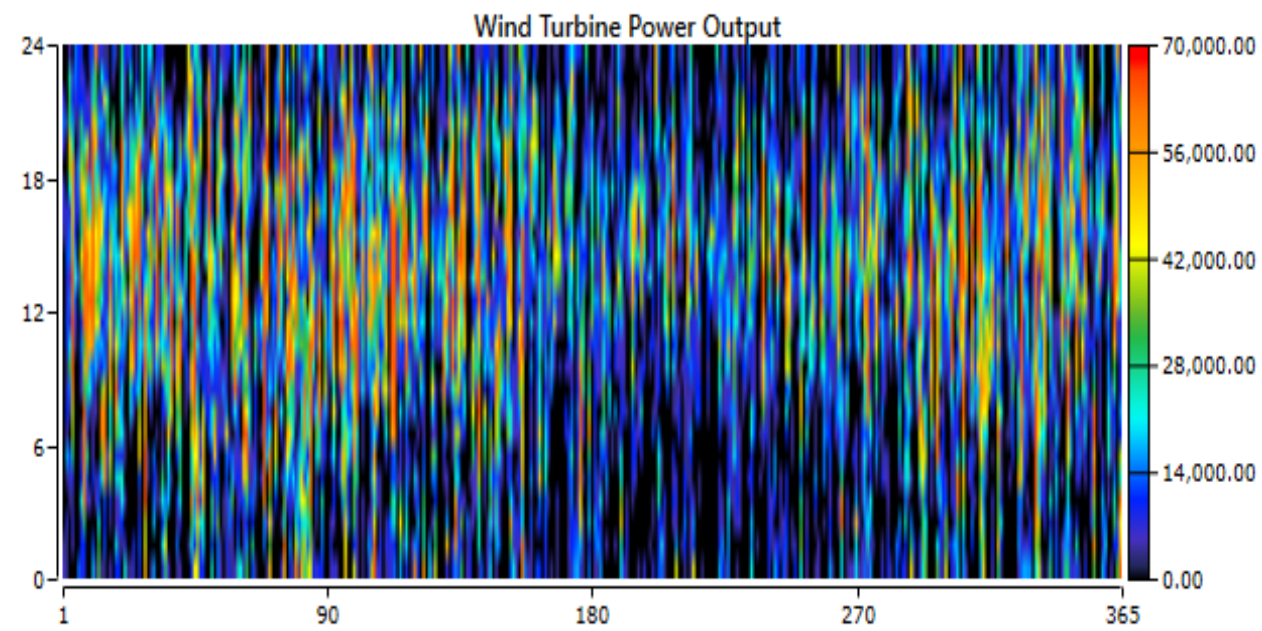

Figure 6. Optimized wind turbine power output. 
The calculated results indicate that currently it would not be economically feasible for the city to become energy independent from the MISO market. The next question is: what would be the most cost-effective amounts of wind and solar energy to make the solution economically feasible? The solution should target at adding the best amount of renewables to offset the purchase from the MISO market. The following discussion compares the optimal system and the desired model that the policy makers may want.

\subsection{Optimized Scenario}

Since the fully independent proposal is proved to be infeasible from an economic standpoint, this optimized scenario suggests a hybrid system that would be financially logical to pursue. It can minimize the dependence on the MISO market to the maximum percentage. The estimate of the initial capital cost of the system is $\$ 4.6$ million dollars with an expected payback period of 11 years. Renewables account for $31 \%$ of the electricity production. The coal power plant provides $20 \%$ of the power. The electrical grid provides the remaining $49 \%$ of electricity. Figures 7 and 8 show the system features. The optimized scenario excludes a battery system or a solar photovoltaic system from the final outcomes due to the high costs associated with investments and O\&M. It adds five $1.5 \mathrm{MW}$ turbines to the current wind turbine system.

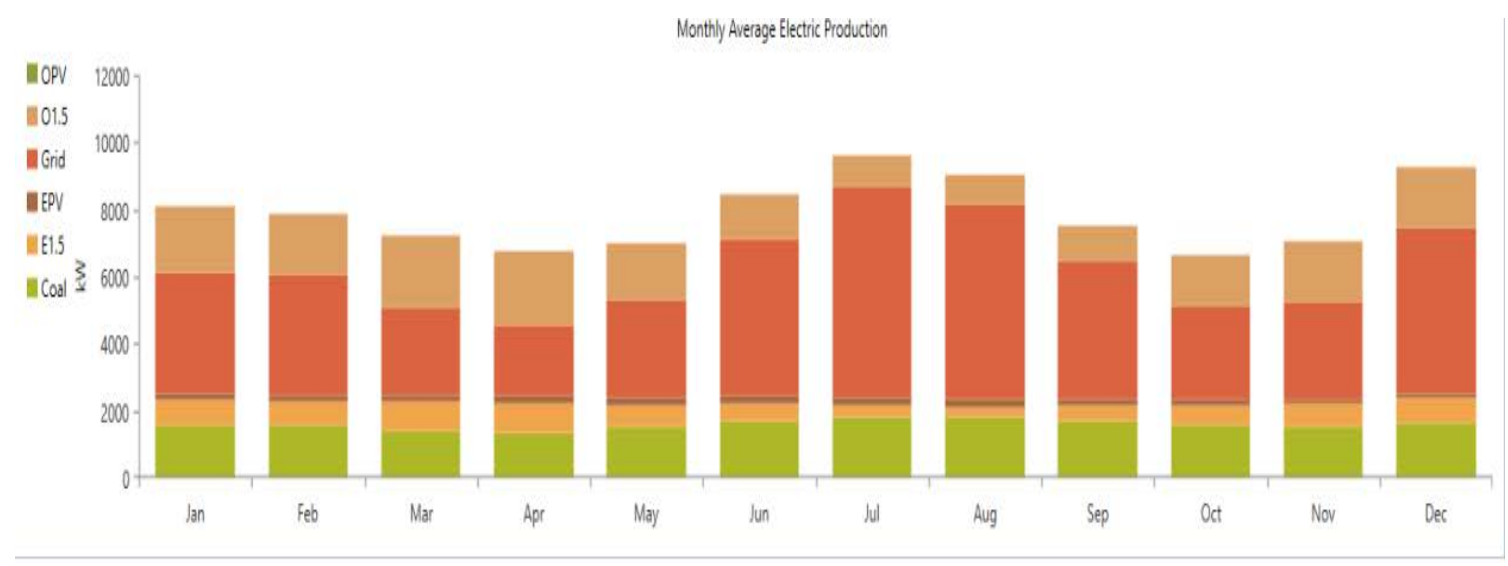

Figure 7. Monthly average energy production of optimized scenario.

\begin{tabular}{|c|c|c|c|c|c|c|c|c|c|}
\hline & & & Component & Capital (\$) & Replacement (\$) & O\&M (\$) & Fuel (\$) & Salvage (\$) & Total (\$) \\
\hline Quantity & Value & Units & $3500 \mathrm{Coal}$ & $\$ 0.00$ & $\$ 0.00$ & $\$ 6,589,826,14$ & $\$ 4,978,979.76$ & $\$ 0.00$ & $\$ 11,568,805,90$ \\
\hline Carbon Dioxide & $35,421,388,36$ & $\mathrm{~kg} / \mathrm{yr}$ & Existing Geneseo PV & $\$ 0.00$ & $\$ 495,393,49$ & $\$ 94,514,35$ & 50.00 & (\$418,822.85) & $\$ 171,084.99$ \\
\hline Carbon Monoxide & $103,294,16$ & $\mathrm{~kg} / \mathrm{yr}$ & Existing Wind turbine & 80.00 & $\$ 643,525.86$ & $\$ 945,143,80$ & $\$ 0.00$ & $(\$ 495,199.09)$ & $\$ 1,093,470.57$ \\
\hline Unburned Hydrocarbons & $4,551.52$ & $\mathrm{~kg} / \mathrm{yr}$ & Generic $1.5 \mathrm{MW}$ & $\$ 8,500,000,00$ & 50.00 & $\$ 2,362,859,54$ & $\$ 0.00$ & $(\$ 238,911.84)$ & $\$ 10,623,947,70$ \\
\hline Particulate Matter & 619.51 & $\mathrm{~kg} / \mathrm{yr}$ & Gid & $\$ 0.00$ & 50.00 & $\$ 40,060,682,41$ & $\$ 0.00$ & $\$ 0.00$ & $\$ 40,060,682,41$ \\
\hline Sulfur Dioxide & $\begin{array}{l}138,422.21 \\
140,61768\end{array}$ & $\mathrm{~kg} / \mathrm{yr}$ & System Converter & $\$ 0.00$ & $\$ 164,526.51$ & $\$ 0.00$ & $\$ 0.00$ & $(\$ 337,329.98)$ & $\$ 127,196.53$ \\
\hline Nitrogen Oxides & $140,617.68$ & & System & $\$ 8,500,000,00$ & $\$ 1,303,445,86$ & $\$ 50,053,026,24$ & $\$ 4,978,979,76$ & $(\$ 1,190,263.76)$ & $\$ 63,645,188.10$ \\
\hline
\end{tabular}

(a)

(b)

Figure 8. (a) Emissions data (b) 25-Year expected cost summary.

\subsection{Desired Scenario}

The survey data of this research reflect the city's expectation that it will increase its renewable energy portfolio to provide $22 \%$ of the production needs in the next 5 to 10 years. The city wants to explore the economic feasibility of adding two 1.5 MW wind turbines, $3 \mathrm{MW}$ solar PV, and $4 \mathrm{MW}$ battery storage. After simulation, the results reveal that the addition of one $1.5 \mathrm{MW}$ wind turbine, 
a 3.5 MW PV solar array, and a 3 MW battery storage system would be sufficient to meet the request. This desired model would produce $23.6 \%$ renewable energy production and offset energy dependence to roughly $53 \%$. The payback period would be 24 years, which is considerably higher than the optimized model. This long payback period is due to the large capital investment for the battery system. Nevertheless, the desired system does decrease the environmental impacts by offsetting close to 5 million $\mathrm{kg} /$ year of $\mathrm{CO}_{2}$ emissions.

In summary, the research found that the implementation of the optimized renewable-energy system may allow the city to become energy independent from the MISO market. However, the required investment for independence is infeasible from an economic standpoint. In particular, in order to achieve an entirely renewable HES, the system requires the following additional capacity: 24.4 MW of solar arrays, 45 1.5 MW-rated wind turbines, and a $177 \mathrm{MWh}$ lithium-ion battery storage system. All these requirements have an estimated initial capital investment of $\$ 184$ million. Instead of relying solely on renewable energies and accomplishing complete independence, the city can proceed with its development strategy in two phases: the first phase is to implement the desired model and the second phase is to build the optimized scenario. In future, the authors will follow up with the city on the operational details of the renewable energy development.

\section{Conclusions}

This paper deliberates a SABP method to obtain the optimized design of an HES system for a small town. Based on the practical conditions, the research considered the main, optimized, and desired scenarios. After completing all the three scenarios, the research summarized the hybrid system requirements, financial parameters, and environmental impacts. HESs must be economically sustainable or they cannot be installed. Clearly there is value in having a more resilient form of energy which hybrid energy systems can provide, but to ignore base load power is inappropriate.

Upon the data analysis of the hypothetical optimized system, the research concluded that the addition of five 1.5 MW wind turbines would be the most beneficial solution. The addition of this system would not allow the city to become completely independent from the MISO market, but does increase its independence as a whole while offering economic benefits. Moreover, the addition of one 1.5 MW wind turbine, a 3.5 MW PV solar array, and a $3 \mathrm{MW}$ battery storage system would be sufficient to meet the requirement for around $22 \%$ renewable energy production. The addition would reduce the city's energy dependence to roughly $53 \%$. Nevertheless, it does stimulate an additional financial investment compared to the optimized scenario.

Renewable energy can be a valid option for the generation of electricity. Yet, it has significant challenges associated with its future development. The variables that must be considered are the amount of renewable energy that can be implemented in an electrical system in a financially and technologically feasible way. The electricity load is a variable that needs to be weighed against how to implement renewable energy and storage technologies. In addition, a true HES creates more than one product to improve the economic performance. The production of the HES studied in this paper only focuses on electric power, because other products are generated by third parties in the market and excluded from this research. From a climate impact perspective, the limitation of this research is that there is no use or reuse of the generated $\mathrm{CO}_{2}$ emissions from the coal plant. The next research step is to explore novel technologies to efficiently utilize other products of HES. In addition, future research on the HES needs to take full advantage of the dynamic nature of solar and wind energy.

Author Contributions: Conceptualization, H.X. and O.E.; Methodology, F.J.; Software, O.E.; Validation, F.J., H.X. and O.E.; Formal Analysis, F.J. and H.X.; Investigation, F.J., H.X. and O.E.; Resources, F.J., H.X. and O.E.; Data Curation, F.J., H.X. and O.E.; Writing-Original Draft Preparation, F.J., H.X. and O.E.; Writing-Review and Editing, F.J. and H.X.; Visualization, H.X. and O.E.; Supervision, F.J. and H.X.; Project Administration, F.J. and H.X.; Funding Acquisition, F.J. and H.X.

Funding: This research received the Jiangsu University “Green and Blue Project" Excellent Teaching Team Project (Project No. JSQLGC2017-TD60) and the Innovation Research Team Project of Taizhou Polytechnic College (Project No. TZYTD-16-5). 
Acknowledgments: The authors acknowledge the administrative and technical support of ISU.

Conflicts of Interest: The authors declare no conflict of interest.

\section{Appendix A}

$$
\begin{gathered}
a^{+}=\text {Sensitivity }= \\
a^{-}=\text {Specificity }=\frac{\text { number of avaliable HES systems that test feasible in expert survey }}{\text { number of HES systems surveyed }} \times 100, \\
\text { number of non }- \text { HES systems surveyed } \\
\frac{\text { Accuracy }=\text { number of correct test results }}{\text { number of systems tested }} \times 100,
\end{gathered}
$$

Notation: + positive result; - negative result; $F E=$ feasible; $N F=$ infeasible; $a^{+}=$sensitivity; $a^{-}=$specificity.

$a^{+} \stackrel{\text { def }}{=} \operatorname{Pr}(+\mid F E)=$ probability that the result is positive, given that the tested system is feasible

$a^{-} \stackrel{\text { def }}{=} \operatorname{Pr}(-\mid N F)=$ probability that result is negative, given that the tested system is infeasible

$$
\text { Accuracy }=a^{+} \operatorname{Pr}(F E)+a^{-} \operatorname{Pr}(N F)
$$

$\theta^{+} \stackrel{\text { def }}{=} \operatorname{Pr}(F E \mid+)=$ probability that system is feasible, given that the test result is positive

$\theta^{-} \stackrel{\text { def }}{=} \operatorname{Pr}(N F \mid-)=$ probability that system is infeasible, given that the test result is negative

The calculation of the test predictability is based on Bayes' formula, the sensitivity and specificity of a test, and the prior probability $(\operatorname{Pr}(F E))$ that a tested system is feasible $[63,64]$.

$$
\begin{aligned}
& \theta^{+}=\operatorname{Pr}(F E \mid+)=\frac{\operatorname{Pr}(F E) \operatorname{Pr}(+\mid F E)}{\operatorname{Pr}(F E) \operatorname{Pr}(+\mid F E)+\operatorname{Pr}(N F) \operatorname{Pr}(+\mid N F)}=\frac{\operatorname{Pr}(F E) a^{+}}{\operatorname{Pr}(F E) a^{+}+\operatorname{Pr}(N F) \operatorname{Pr}\left(1-a^{-}\right)} \\
& \text {Since } \left.\operatorname{Pr}(-\mid N F)=a^{-}\right) \text {and } \operatorname{Pr}(-\mid N F)+\operatorname{Pr}(+\mid N F)=1, \operatorname{Pr}(+\mid N F)=1-a^{-} \\
& \theta^{-}=\operatorname{Pr}(N F \mid-)=\frac{\operatorname{Pr}(N F) \operatorname{Pr}(-\mid N F)}{\operatorname{Pr}(N F) \operatorname{Pr}(-\mid N F)+\operatorname{Pr}(F E) \operatorname{Pr}(-\mid F E)}=\frac{\operatorname{Pr}(N F) a^{-}}{\operatorname{Pr}(N F) a^{-}+\operatorname{Pr}(F E) \operatorname{Pr}\left(1-a^{+}\right)}
\end{aligned}
$$

To preliminarily select tests in order to form a series of tests, this research considers the "majority" rule [40]. For example, an odd number of tests should be used to make the most decisive series. Table A1 shows the classification of tests. The tests in Class I are good predictor and good selector tests. If tests in Class I are available and statistically independent, use as many of them as is cost effective. A test in Class II should always be coupled with a test from Class III. Overall, the selection should avoid taking the tests in Class IV. 
Table A1. Scheme for test classification.

\begin{tabular}{ccccc}
\hline Potential Use of Tests & Class I & Class II & Class III & Class IV \\
\hline Criteria $^{1}$ & $0.75<a^{+} \leq 1$ & $0.75<a^{+} \leq 1$ & $0 \leq a^{+} \leq 0.75$ & $0 \leq a^{+} \leq 0.75$ \\
Description $^{2}$ & $0.75<a^{-} \leq 1$ & $0 \leq a^{-} \leq 0.75$ & $0.75<a^{-} \leq 1$ & $0 \leq a^{-} \leq 0.75$ \\
Checking Feasibility $_{\text {Checking Infeasibility }}$ & $a^{+}: \mathrm{M}$ to H & $a^{+}: \mathrm{M}$ to H & $a^{+}: \mathrm{L}$ to M & $a^{+}: \mathrm{L}$ to M \\
Predicting Feasibility & $a^{-}: \mathrm{M}$ to H & $a^{-}: \mathrm{L}$ to M & $a^{-}: \mathrm{M}$ to H & $a^{-}: \mathrm{L}$ to M \\
Predicting Infeasibility & $\theta^{+}: \mathrm{M}$ to H & $\theta^{+}: \mathrm{L}$ to M & $\theta^{+}: \mathrm{M}$ to H & $\theta^{+}: \mathrm{L}$ to M \\
\hline
\end{tabular}

${ }^{1}$ A test with at least $75 \%$ accuracy as a reasonably good test. ${ }^{2} \mathrm{~L}$, Low; $\mathrm{M}$, Moderate; $\mathrm{H}$, High.

\section{References}

1. Neves, D.; Silva, C.A.; Connors, S. Design and implementation of hybrid renewable energy systems on micro-communities: A review on case studies. Renew. Sustain. Energy Rev. 2014, 31, 935-946. [CrossRef]

2. Khare, V.; Nema, S.; Baredar, P. Solar-wind hybrid renewable energy system: A review. Renew. Sustain. Energy Rev. 2016, 58, 23-33. [CrossRef]

3. Twidell, J.; Weir, T. Renewable Energy Resources; Routledge: London, UK, 2015.

4. United Nations Department of Economic and Social Affairs. Sustainable Development Knowledge Platform. Available online: https:/ / sustainabledevelopment.un.org/sdg7 (accessed on 20 May 2018).

5. Jacobsson, S.; Lauber, V. The politics and policy of energy system transformation-Explaining the german diffusion of renewable energy technology. Energy Policy 2006, 34, 256-276. [CrossRef]

6. Kim, K.; Kim, Y. Role of policy in innovation and international trade of renewable energy technology: Empirical study of solar PV and wind power technology. Renew. Sustain. Energy Rev. 2015, 44, 717-727. [CrossRef]

7. Ahlborg, H.; Sjöstedt, M. Small-scale hydropower in Africa: Socio-technical designs for renewable energy in tanzanian villages. Energy Res. Soc. Sci. 2015, 5, 20-33. [CrossRef]

8. Glassley, W.E. Geothermal Energy: Renewable Energy and the Environment; CRC Press: Boca Raton, FL, USA, 2014.

9. Scarlat, N.; Dallemand, J.-F.; Monforti-Ferrario, F.; Banja, M.; Motola, V. Renewable energy policy framework and bioenergy contribution in the european union-An overview from national renewable energy action plans and progress reports. Renew. Sustain. Energy Rev. 2015, 51, 969-985. [CrossRef]

10. Cheng, J. Biomass to Renewable Energy Processes; CRC Press: Boca Raton, FL, USA, 2017.

11. El-Ashry, M. Renewables 2010 Global Status Report; REN21 Secretariat, Copyright Deutsche (GTZ) GmbH: Paris, France, 2010.

12. Sawin, J.L.; Sverrisson, F.; Seyboth, K.; Adib, R.; Murdock, H.E.; Lins, C.; Edwards, I.; Hullin, M.; Nguyen, L.H.; Prillianto, S.S. Renewables 2017 Global Status Report; International Atomic Energy Agency (IAEA): Vienna, Austria, 2013.

13. Olasolo, P.; Juárez, M.; Morales, M.; Liarte, I. Enhanced geothermal systems (EGS): A review. Renew. Sustain. Energy Rev. 2016, 56, 133-144. [CrossRef]

14. Shortall, R.; Davidsdottir, B.; Axelsson, G. Geothermal energy for sustainable development: A review of sustainability impacts and assessment frameworks. Renew. Sustain. Energy Rev. 2015, 44, 391-406. [CrossRef]

15. De Menna, F.; Vittuari, M.; Molari, G. Impact evaluation of integrated food-bioenergy systems: A comparative LCA of peach nectar. Biomass Bioenergy 2015, 73, 48-61. [CrossRef]

16. Bonar, P.A.; Bryden, I.G.; Borthwick, A.G. Social and ecological impacts of marine energy development. Renew. Sustain. Energy Rev. 2015, 47, 486-495. [CrossRef]

17. Neary, V.S.; Lawson, M.; Previsic, M.; Copping, A.; Hallett, K.C.; LaBonte, A.; Rieks, J.; Murray, D. Methodology for Design and Economic Analysis of Marine Energy Conversion (MEC) Technologies; VirginiaTech: Blacksburg, VA, USA, 2014.

18. Zhao, H.; Wu, Q.; Hu, S.; Xu, H.; Rasmussen, C.N. Review of energy storage system for wind power integration support. Appl. Energy 2015, 137, 545-553. [CrossRef] 
19. Malmstrom, T.K.; Voss, V.; Cruz-Oliver, D.; Cummings-Vaughn, L.; Tumosa, N.; Grossberg, G.; Morley, J. The rapid cognitive screen (RCS): A point-of-care screening for dementia and mild cognitive impairment. J. Nutr. Health Aging 2015, 19, 741-744. [CrossRef] [PubMed]

20. Heredia, F.J.; Cifuentes-Rubiano, J.; Corchero, C. Research article: Stochastic optimal generation bid to electricity markets with emissions risk constraints. J. Environ. Manag. 2018, 207, 432-443. [CrossRef] [PubMed]

21. Rubin, O.D.; Babcock, B.A. The impact of expansion of wind power capacity and pricing methods on the efficiency of deregulated electricity markets. Energy 2013, 59, 676-688. [CrossRef]

22. Grubb, M.; Butler, L.; Twomey, P. Diversity and security in UK electricity generation: The influence of low-carbon objectives. Energy Policy 2006, 34, 4050-4062. [CrossRef]

23. Domínguez, C.; Antón, I.; Sala, G. Solar simulator for concentrator photovoltaic systems. Opt. Express 2008, 16, 14894-14901. [CrossRef] [PubMed]

24. Granqvist, C.G. Transparent conductors as solar energy materials: A panoramic review. Sol. Energy Mater. Sol. Cells 2007, 91, 1529-1598. [CrossRef]

25. Mor, G.K.; Varghese, O.K.; Paulose, M.; Shankar, K.; Grimes, C.A. A review on highly ordered, vertically oriented tio2 nanotube arrays: Fabrication, material properties, and solar energy applications. Sol. Energy Mater. Sol. Cells 2006, 90, 2011-2075. [CrossRef]

26. Solangi, K.; Islam, M.; Saidur, R.; Rahim, N.; Fayaz, H. A review on global solar energy policy. Renew. Sustain. Energy Rev. 2011, 15, 2149-2163. [CrossRef]

27. EngineeringToolBox. Fuels-Higher Calorific Values. Available online: http:/ / www.engineeringtoolbox. com/fuels-higher-calorific-values-d_169.html (accessed on 27 April 2018).

28. Classification of Coal. Engineering Tool Box. Available online: http://www.engineeringtoolbox.com/ classification-coal-d_164.html (accessed on 27 April 2018).

29. The Engineering ToolBox. Solids and Metals-Specific Gravities. Available online: https://www. engineeringtoolbox.com/specific-gravity-solids-metals-d_293.html (accessed on 1 February 2018).

30. Parida, B.; Iniyan, S.; Goic, R. A review of solar photovoltaic technologies. Renew. Sustain. Energy Rev. 2011, 15, 1625-1636. [CrossRef]

31. Tachibana, Y.; Vayssieres, L.; Durrant, J.R. Artificial photosynthesis for solar water-splitting. Nat. Photonics 2012, 6, 511. [CrossRef]

32. Schlaich, J.; Bergermann, R.; Schiel, W.; Weinrebe, G. Design of commercial solar updraft tower systems-Utilization of solar induced convective flows for power generation. J. Sol. Energy Eng. 2005, 127, 117-124. [CrossRef]

33. Buchheit, K.L.; Chen, C.; Guntupalli, U.; Smith Joseph, D. Techno-economic analysis of a sustainable coal, wind, and nuclear hybrid energy system. Energy Fuels 2016, 30, 10721-10729. [CrossRef]

34. Yousefi, H.; Ghodusinejad, M.H. Feasibility study of a hybrid energy system for emergency off-grid operating conditions. Majlesi J. Electr. Eng. 2017, 11, 7-14.

35. Ramli, M.A.; Hiendro, A.; Twaha, S. Economic analysis of PV/diesel hybrid system with flywheel energy storage. Renew. Energy 2015, 78, 398-405. [CrossRef]

36. Perera, A.; Attalage, R.; Perera, K.; Dassanayake, V. A hybrid tool to combine multi-objective optimization and multi-criterion decision making in designing standalone hybrid energy systems. Appl. Energy 2013, 107, 412-425. [CrossRef]

37. Dalton, G.; Lockington, D.; Baldock, T. Case study feasibility analysis of renewable energy supply options for small to medium-sized tourist accommodations. Renew. Energy 2009, 34, 1134-1144. [CrossRef]

38. Robins, J. Case Study: Feasibility Analysis of Renewable Energy Supply Systems in a Small Grid Connected Resort. Master's Thesis, University of Nevada, Las Vegas, NV, USA, 2009.

39. Homer Energy. Homer Pro Version 3.7 User Manual. August 2016. Available online: https://www. homerenergy.com/pdf/HOMERHelpManual.pdf (accessed on 15 June 2018).

40. Haimes, Y.Y. Risk Modeling, Assessment, and Management; John Wiley \& Sons: New York, NY, USA, 2015.

41. Woodard, C. America's First All-Renewable-Energy City. Available online: https://www.politico.com/ magazine/story/2016/11/burlington-what-works-green-energy-214463 (accessed on 14 June 2018).

42. Jo, J.H.; Loomis, D.; Aldeman, M. Optimum penetration of utility-scale grid-connected solar photovoltaic systems in Illinois. Renew. Energy 2013, 60, 20-26. [CrossRef] 
43. Gupta, S. PV-Wind Hybrid System: A Review with Case Study. Available online: http:/ /www.tandfonline. com/doi/full/10.1080/23311916.2016.1189305 (accessed on 3 March 2018).

44. Akuru, U.B.; Onukwube, I.E.; Okoro, O.I.; Obe, E.S. Towards 100\% renewable energy in Nigeria. Renew. Sustain. Energy Rev. 2017, 71, 943-953. [CrossRef]

45. VENSYS. Vensys Energy AG-Vensys $1.5 \mathrm{mw}$ Platform. Available online: http://www.vensys.de/energyen/produkte-und-service/vensys-1-5-mw.php (accessed on 20 February 2018).

46. EIA.Gov. How Much Coal, Natural Gas, or Petroleum Is Used to Generate a Kilowatt-Hour of Electricity? Available online: https:/ / www.eia.gov/tools/faqs/faq.php?id=667\&t=2 (accessed on 27 April 2018).

47. Coal Prices and Charts. Quandl.Com. Available online: https://www.quandl.com/collections/markets / coal (accessed on 20 May 2018).

48. Yan, H.; Chen, S.; Dong, M.; Zhou, X.; Chen, X. A Day-Ahead Scheduling Strategy of Incentive Demand Response under Retail Power Market Deregulation; IEEE: Washington, DC, USA, 2017; p. 294.

49. City of Geneseo, E.U. Available online: http://www.cityofgeneseo.com/electric-utility (accessed on 20 May 2018).

50. MISO. Database of Midcontinent Independent System Operator Inc. Available online: https://www. misoenergy.org/ (accessed on 20 May 2018).

51. Jones, K. An examination of prices on the miso exchange. Res. Financ. 2018, 34, 57.

52. Source Watch. Louisa Generating Station-Source Watch. Available online: http:/ /www.sourcewatch.org/ index.php/Louisa_Generating_Station (accessed on 27 April 2018).

53. Coal Explained. Coal Explained-Coal Prices and Outlook. Available online: https://www.eia.gov/ energyexplained/index.cfm?page=coal_prices (accessed on 27 April 2018).

54. EIA. Electricity Data of EIA. Available online: https://www.eia.gov/electricity/monthly/epm_table_ grapher.cfm?t=epmt_6_07_a (accessed on 27 April 2018).

55. The National Renewable Energy Laboratory (NREL). National Renewable Energy Lab Database; The U.S. Department of Energy, Office of Energy Efficiency and Renewable Energy, Ed.; NREL: Washington, DC, USA, 2017.

56. The Renewable Resource Data Center (RREDC). National Solar Radiation Data Base; National Renewable Energy Laboratory, Ed.; NREL: Washington, DC, USA, 2017.

57. The National Aeronautics and Space Administration (NASA) (Ed.) Surface Meteorology and Solar Energy: A Renewable Energy Resource Web Site (Release 6.0); NASA: Washington, DC, USA, 2017.

58. Aydin, N.Y.; Kentel, E.; Duzgun, H.S. GIS-based site selection methodology for hybrid renewable energy systems: A case study from western turkey. Energy Convers. Manag. 2013, 70, 90-106. [CrossRef]

59. Østergaard, P.A. Reviewing optimisation criteria for energy systems analyses of renewable energy integration. Energy 2009, 34, 1236-1245. [CrossRef]

60. NREL.Gov. U.S. Solar Photovoltaic System Cost Benchmark: Q1 2016. Available online: http: / / www.nrel.gov / docs / fy16osti / 66532.pdf?utm_source=NREL\%20Report\%20Shows\%20U\% 2ES\%2E\%20Solar\%20Photovoltaic\%20Costs\%20Continuing\%20to\%20Fall\%20in\%202016\&utm_medium= email\&utm_content=nrel\&utm_campaign=NewsRelease (accessed on 20 April 2018).

61. Labrador, D. A Small Iowa Town Embraces Energy Independence. Available online: https:/ /www.greenbiz. com/article/small-iowa-town-embraces-energy-independence (accessed on 3 March 2018).

62. Romm, J. Chart of the Month: Driven by Tesla, Battery Prices Cut in Half Since 2014. Available online: https: / / thinkprogress.org/chart-of-the-month-driven-by-tesla-battery-prices-cut-in-half-since2014-718752a30a42 (accessed on 20 May 2018).

63. Leemis, L.M. Reliability: Probabilistic Models and Statistical Methods; Prentice-Hall, Inc.: Upper Saddle River, NJ, USA, 1995.

64. Pratt, J.W.; Raiffa, H.; Schlaifer, R. Introduction to Statistical Decision Theory; MIT Press: Cambridge, MA, USA, 1995.

(C) 2018 by the authors. Licensee MDPI, Basel, Switzerland. This article is an open access article distributed under the terms and conditions of the Creative Commons Attribution (CC BY) license (http:/ / creativecommons.org/licenses/by/4.0/). 